\title{
ON FACTORS AFFECTING FOLKLORISTIC FIELDWORK: ON THE EXAMPLE OF ESTONIANS IN SIBERIA
}

\section{Anu Korb}

\begin{abstract}
Estonians in Siberia are the descendents of the Estonians deported by the Russian Tsar in the 18th-19th century, and of voluntary emigrants who left Estonia during the final decade of the 19th century and the beginning of the 20th century.

The article observes the main factors that have influenced the results of folkloristic fieldwork on collecting Estonian folklore in Estonian communities in Siberia during 1991-2000. The author has also pointed out that the contacts of Estonians living in Siberia with their homeland have become scarcer due to economic and socio-political reasons after Estonia regained independence.

Proceeding from the view that fieldwork results depend on the reciprocal cooperation of two parties, the collector and informant, the factors affecting fieldwork from either aspect - from the aspect of collector and that of the informant - are analysed separately. The article observes to which extent does the scholar's approach to members of a lore group depend on his or her background culture and education, how the collector's gender and personal characteristics, his or her competence in the communication system of a lore group and recording devices affect the result. The author also analyses the role of lore group members in the development of the fieldwork results: the control of a single individual and of the whole lore group on the narrative material, the role of a lore group leader, rivalry among informants, and the influence of interviewee's family members on the collected material.
\end{abstract}

Keywords: fieldwork, Siberian Estonians

Estonians in Siberia are the descendents of Estonians deported from homeland in the 18th-19th century, and voluntary emigrants who left Estonia during the final decade of the 19th century and the beginning of the 20th century (see Korb 2000: 48-52). During the period 1991-2000 I worked with 2-4 members of our expedition group in the Estonian settlements in Siberia, located in the area from the Omsk Oblast to Krasnoyarsk District, with a purpose to assess the survival of Estonian communities in Siberia.

Scholars who use fieldwork to collect oral history quite unanimously agree that the final result is largely dependent on the reciprocal 
interaction of collector and informant. Factors influencing fieldwork can be generally divided in two major groups with the decisive criterion being the significance of one party's (either scholar's or lore group member's) role over the other. The factors, however, are not independent or isolated, as they emerge in the interaction of collector and informant. Thus factors affecting fieldwork are closely interrelated with both parties and with each other. The purpose of this article is to point out the main factors that have influenced the collection of Estonian folklore in Siberia, and to indicate how this influence has manifested itself.

\section{COLLECTOR-DEPENDENT FACTORS}

\section{a. Collector's knowledge (education, work experience) and background.}

During fieldwork a folklorist's approach to members of a lore group largely depends on his or her ethnic culture, education, experience in archival work and also earlier fieldwork experience. A decisive aspect of folkloristic fieldwork is what is considered a part of folkloric collection work and research in a particular culture at a particular moment of time, and which methods are used in gathering folkloric material. Thus a folklore collector conducting fieldwork relies on his or her cultural patterns and educational background. Users of the geographic-historical research method focused their attention mainly to a publication of folklore. Today folklore is no longer understood as legacy of the past, but as a common lore of any social group. The type-centred definition of folklore was replaced by the functional definition, and the focus was shifted from folklore publications to understanding the individual and the functioning collective (Honko 1998: 57, 60). Modern recording technology has provided considerably better opportunities for observing the context and the meaning.

When starting out with fieldwork in the Estonian settlements in Siberia, I viewed the work as preservative collecting - I tried to preserve as much old and archaic lore as possible, as such approach to material was predominant amongst the Estonian folklorists. Owing to the opening of broader collection topics and the study of 


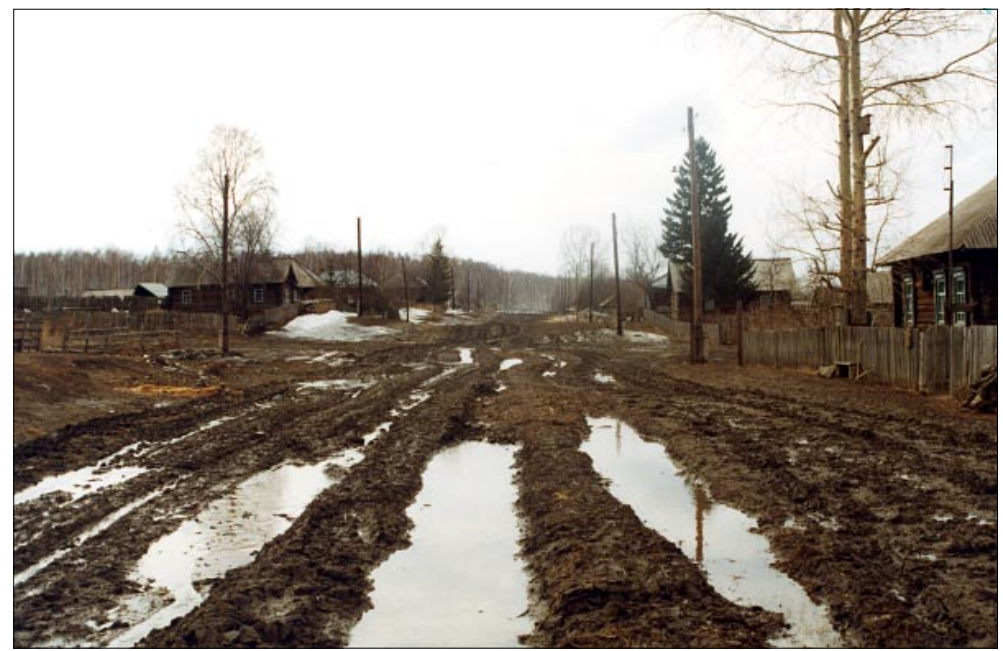

Photo 1. Spring in Estonka village. Photo by Risto Järv, 1998. EFA photo archives, photo no. 971 .

several fieldwork notes and relying on my practical fieldwork experience, my approach to the material changed critically: paying more attention to context and meaning and registering situational material that informants viewed as important became the focus of my research.

It is possiblethat no folklore collector succeeds in interviewing an informant and finding out all the lore he or she might know, especially in a limited time frame. No folklore collector is equally competent in all areas of folklore - everyone has his or her favourite topics, what he or she feels familiar with. The goal of a particular collector in fieldwork may often be a specific area that he or she is studying. Often, of course, the collector receives information that he or she has not necessarily asked for, or that the informant considers important. But it is advisable to register such material, because material collected this way may later become a source for new interpretations (see e.g. Aro 1996) and the material stored in the archives may prove useful for other scholars. A folklore collector is unable to approach fieldwork collecting from folkloristic, eth- 
nological and sociological viewpoint at the same time, but the folklore of Estonians in Siberia may prove an interesting source for comparative studies for the scholars of neighbouring areas. A collector who studies folklore in Siberia should be as comprehensive as possible, as the distance and costly travel expenses limit the number of scholars who can visit Siberia (at least this is the situation in Estonia today).

A folklore collector of Estonian origin usually receives from Estonian informants in Siberia material that the informants regard as natively Estonian, as something belonging to the Estonian tradition. The informants, for example, try to sing in the Estonian language more often than is customary in the multiethnic community in Siberia. When I let the informants to choose their song repertoire, I heard the more popular and well-learned songs of a particular song group, but the repertoire included less Russian songs than were used in everyday practice. In multicultural communities foreign influences are often transmitted unconsciously - e.g. SiberianEstonian singers of the age 50-60 and younger exhibit a characteristic way of singing, which is typical for a Russian cultural environment, i.e. they sing slower than native Estonians and use a more open and intense tone (see Pärtlas 1995: 58), often unconsciously. As to other genres the preference of native tradition is less noticeable, although the informants are often aware of the line between familiar and unfamiliar. A description of a custom may, for example, begin with words: Now they have adopted this Russian way... Sometimes, an informant may be reluctant to describe a non-native custom.

\section{b. Competence in the communicational system of the lore group}

Here I mean the communicational system of the whole lore group, which enables the scholar to communicate and interpret the message with members of a lore group, including language, gestures, facial expressions, tone of voice, etc.

Folklorists and anthropologists have begun to speculate on the importance of speaking a local language only in the second half of the 20th century, although several scholars (Zola Neale Hurston, for 
example) have drawn attention to this issue even earlier (Stoeltje, Fox, Olbrys 1999: 163). However, the use of a mediating language in recording foreign culture is not particularly rare even nowadays. For example, the communication between the collectors of Finno-Ugric folklore in Russia and the local informants often takes place in Russian, since most collectors do not understand the local language, whereas the local Finno-Ugrians are able to communicate in the Russian language. Ethnography students and postgraduates of the Omsk University also use Russian during fieldwork in the Estonian and Latvian villages in Siberia. Their area of interest is mostly collecting data on ethnic processes, and less recording informant lore. A serious conflict between the two different cultures occurs when members of a lore community are asked to describe phenomena of the spiritual world rather than the physical world. Searching for equivalents of concepts in either language may prove a burdensome task and requires competence both in culture and language (see Barkalaja 2000: 180-181). Proficiency in the native language of the lore group is therefore of major importance for a folklore collector. I personally realised the advantages of collecting in native language during recording the lore of single non-Estonians, namely the Latvians in the village of Ryzhkovo - my lack of understanding the informant's native language became an obstacle in in-depth interviewing. A mediating foreign language will convey the plot and mode of expression, while the individual style remains lost. The situation is even worse in terms of short forms, wordplay, etc., where the collector's incompetence may be damaging to the contents. Inadequate language skills, such as, for example, inability to understand local dialect, may inhibit the collector's ability to collect data, as he may fail to understand the contents, or cause misinterpretations (Briggs 1986a: 44). Mexican-born scholar Americo Paredes (1993) describes the conflict between the lore group and scholars from different cultures - members of the lore community sensed that their reality has been misunderstood and misrepresented in studies. Similar dangers may await a collector among the Siberian Estonians.

The Estonian language in Siberia differs considerably from the standard Estonian language, and language usage displays regional varieties. The settlements may be roughly divided into South Estonian dialectal areas and North Estonian dialectal areas. Many inhabit- 
ants of mostly older North Estonian villages have come from different parts of North Estonia and have developed a common language variety that has no exact counterpart in Estonia (Viikberg, Vaba 1984: 216). Those who emigrated from South Estonia usually came from a narrower region and have clearly retained the idiosyncratic features of this variety. Both varieties include Russian words or phrases and Russian loans adapted to the Estonian pronunciation, whereas the variety of North Estonian emigrants includes various Finnish loans and Finnishisms (see Viikberg, Vaba 1984: 220-221). The language variety of the oldest Lutheran settlement in Siberia, the village of Ryzhkovo, differs from others in that people use four languages there, the Estonian, Latvian, Finnish, Russian, whereas none of these in their standard literary form.

The Siberian Estonians are generally embarrassed of their language usage, which differs from the literary language and therefore highly value their mother tongue. The same has been noted by collectors of Finnish lore in Ingermanland (see Pekkala, Vasenkari 2000: 566). As a collector I have tried to encourage my informants to express themselves freely, explaining the difference of regional varieties and assuring them that I wish to hear the authentic Siberian variety and that I can understand it perfectly.

Another problem that a folklore collector in Siberia might encounter is how to make sure that the informant understands you. For example, the Siberians don't understand many words that have entered the native Estonian language in the past decades. Often, the collector needs to paraphrase the question or explain it further. It is also quite important to be familiar with the lore group's vocabulary. Gillian Bennett, who studies legends, has pointed out the same, claiming that during an interview with the elderly women in Manchester she managed to establish comfortable conversational situation only after she adopted the vocabulary that was used by her informants (Bennett 1999: 176). Having interviewed the Siberian Estonians I agree with her conclusion. Earlier experience of the life in Siberia is extremely useful even on the first visit to some village, as the collector is familiar with most of the common vocabulary of the Siberian Estonians. My Siberian informants have often told me: You speak like me. The older generation of the Siberian Estonians have studied Estonian language at school (until about 
the year 1937), but the interviewer's literary language usage have rarely any effect on the informant's language (differing, in this sense, from the dialectal areas in Estonia).

Misunderstanding may also happen due to some latent reasons, being cultural, psychological, socio-political, etc. Americo Paredes (1993: 197) discusses the strategies of special performance and points out how the collector may fail when it happens. One and the same text may have different meanings, depending on the context and situation and the way it is uttered. Charles Briggs argues that many scholars fail because they rely on the metacommunicative habits of their own language environment, instead of those of given lore group (Briggs 1986: 2). Thus, being able to speak the informants' language will not guarantee perfect understanding, but is still an important prerequisite.

\section{c. Using recording devices}

Nowadays it is considered quite natural that a tape-recorder and/or a video recorder and a camera form a part of a folklore collector's standard equipment. Most contemporary folklorists do not rely only on memory and use technology. Some even claim they cannot trust a collector who only takes notes (Jackson 1987: 83). Thus, while formerly a collector brought only his or her version from the fieldwork expedition, now audio and video recorders enable to present the performer's version.

The acquired importance of recording devices as fieldwork tools has brought along the need for instruction in the field. Some universities, the University of Göttingen for example, have included making ethnological documentaries in their curricula (Brednich 1988: 90).

Video technology is almost indispensable in recording rituals, even though a camera may not be able to capture the entire ritual in case some activities take place elsewhere. In this case the scholar must carefully choose what to record (see also Lipponen 1999: 147). Progress in recording technology has considerably expanded areas of study - for example, studies about performance and context. Recording of games, dances, process of rituals seems unthinkable without a video camera. A video recording even provides new opportu- 


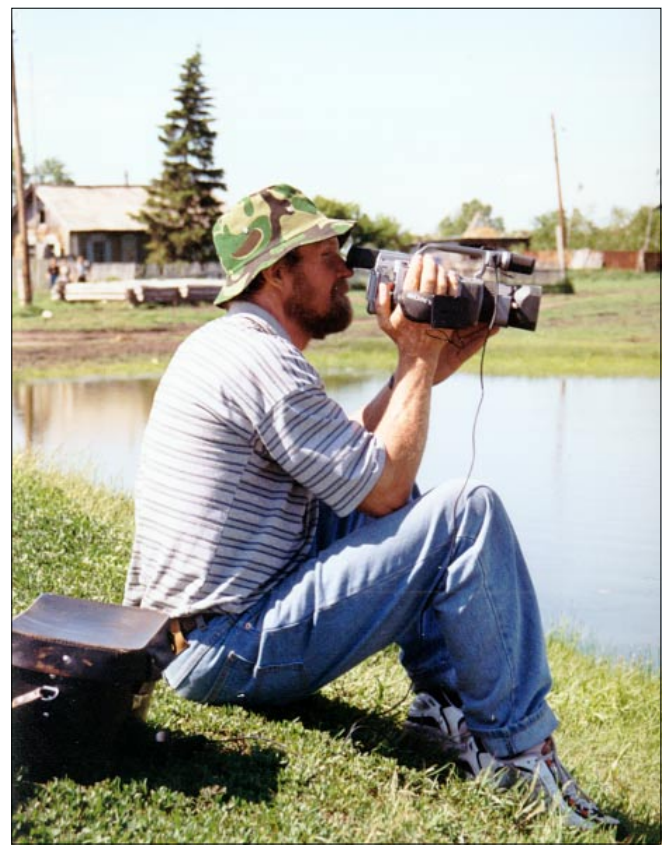

Photo 2. Andres Korjus at filming during fieldwork in Nikolaevka, Siberia. Photo by Astrid Tuisk, 1999. EFA photo archives, photo no. 3657.

nities for studying ritual symbols - while watching the recorded material an informant can simultaneously explain what is happening (Virtanen 1988: 57). Looking at photographs with the informant could have the same result. While recording sacred rituals, folklorists often face the issue of how far can one interfere with recording a foreign culture. At the Pärnu festival of visual anthropology, A. Mikhailov, a film director from Tomsk, commented on his documentary "Visiting Evuk-ik" that he choose not to film these parts of the ritual that could possibly harm the participants if it became public (Rüütel 2000: 174). A scholar who has managed to establish a friendly contact with members of the lore community, often intuitively makes the right choice of conduct. The general principle is if you think that your recording will harm anyone, leave it undone. 
As to recording, B. Jackson (1987: 100) has pointed out that a collector, if too relaxed, is in danger of forgetting what he or she has been told. Perhaps it happens because of the inevitable limits of human capacity: the collector needs to operate and observe the technical device, establish trusting relations with the informant, direct the interview, filling unnatural breaks in conversation, etc. at the same time. This is simply too much for one person and since the recorder registers everything there is no need to remember all the details of the visit.

Another issue related to the use of recording devices is informant's techno- or mechanophobia. Some authors, e.g. Jackson (1987: 84) claim that unlike twenty or so years ago, recording devices are so common these days that require no further discussion, explanation or justification. He considers issues with mechanophobia traceable back to the interviewer - when he or she fears that the microphone might cause discomfort, then it usually will (Jackson 1987: 85). As to Estonians in Siberia I cannot quite agree with B. Jackson - in most Siberian villages, recording devices still attract attention and are not commonly used. Some interviewees are still uncomfortable when recording devices, especially video cameras, are suddenly set up. In spring 1999 in the village of Nikolaevka, for example, our hostess was seriously startled when the camera operator wished to record our arrival. Some collectors hope to gradually get their interviewees accustomed with cameras by taking these along even when they do not plan to use them, hoping that they will eventually pay no notice (Jackson 1987: 88). To my mind, there is a considerable difference between taking the device along and using it.

Single interviewees have posed serious problems in recording situations: in this case a collector has no chance to check the recording device, as even a single glance on the camera prompts the interviewee's question whether the camera is working properly. While working with such informants I try not to look towards the camera, and give priority to storing information rather than technical quality. An interviewer cannot, however, disregard the recording devices entirely and has to occasionally insert a new disc or tape.

Certainly, not all informants feel discomfort when speaking to a camera. On the contrary - most of them are quite comfortable with recording. During my early expeditions I never took a camera out 
at once, but first made casual small-talk and only then started recording. Later I realised that by doing so I lost valuable and unique information, which I could register only partly afterwards. An informant may comment on the most intriguing material already at the very beginning of the conversation. Recently I have started recording almost at the beginning of my interview. And, indeed, when I get the minidisk ready while casually talking to the informant, it does not startle my interviewees. A recording situation may be advantageous also from the informant's point of view: the eye contact with the interviewer is maintained, the informant's words are accurately registered, etc. The use of a recording device, however, may sometimes alter the performance, interfering directly with the performance situation (see e.g. Tedlock 1983: 286; Ives 1995: 69). American anthropologist Dennis Tedlock describes how a Zuni storyteller censured his story not in the presence of women and children, but in a recording situation in the presence of an audience of adult men (Tedlock 1983: 292). I have noticed a similar problem during recording the obscene, personally intimate or discreet tradition on my Siberian fieldwork expeditions. Some things are confided to the interviewer only after the tape recorder has been switched off. A female informant, before confiding me the most indiscreet part of her story, asked me: Don't put it on the tape! Should not, what I will tell you now. Should not, this cannot go there. From a collector's viewpoint this may often be a very interesting material and the interviewer may even be tempted to record it without the informant's consent. But can we, scholars, disregard the informant's will even for strictly scholarly purposes?

I believe that cameras tend to interfere with human interaction more than audio recording devices do. Eye contact with the interviewee, which is impossible to maintain with a video camera, facilitates the establishment of mutually confiding relationship. The problem here is that in the presence of camera people tend to act differently, losing natural behaviour and the recording is as if staged. The same may occur also during the audio recording - the informant carefully chooses words, topics, acts unnaturally, etc., though in this case the influence is considerably weaker.

The camera operator and the interviewer may often be two persons, whereas the operator may not always be a folklorist. Thus, 


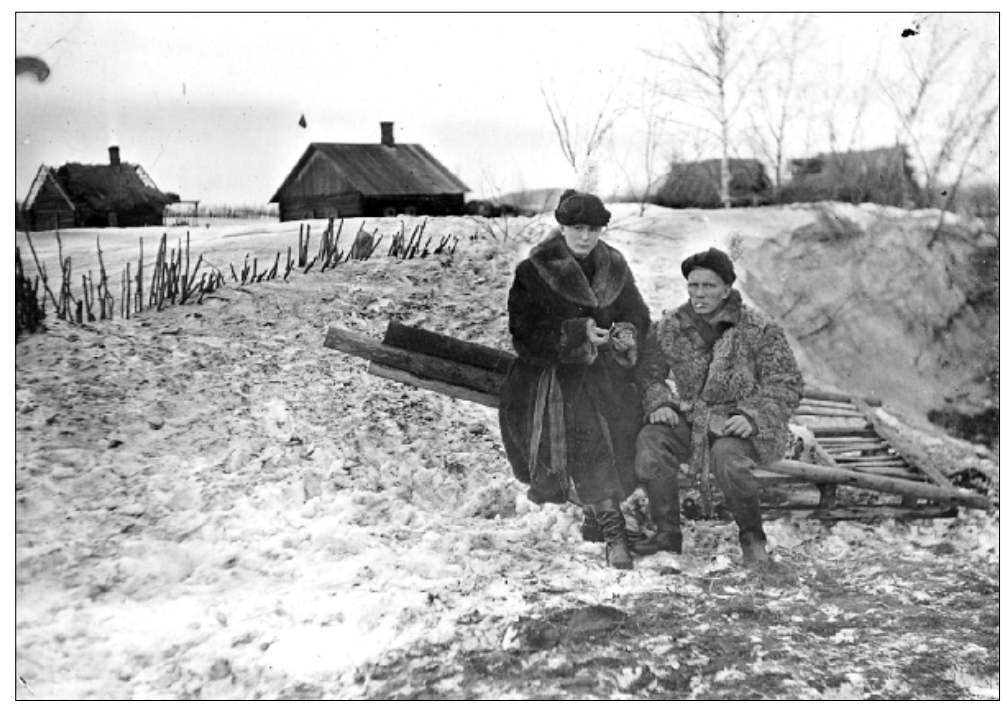

Photo 3. Men with a wedding gun, photographed in Yuryev village in the 1950s. Photo provided by Tamara Soots.

his or her expectations of the recorded material may be widely different from those of a folklore collector. A cameraman who wishes to collect material for an (artistic) documentary, shoots nature scenes, records certain sounds, etc. and may partly or totally disregard a song, story or a dance, which is of primary importance to a folklorist.

The traditional purposes of taking photos at fieldwork follow three principles: 1) the photographs should provide visual description, thus complementing the collected data, 2) they should be illustrative enough to be used in lectures and printed publications, and 3) they could be used as presents to informants to encourage the latter to cooperation. The importance of a photograph in collecting information may, in fact, be even greater (see e.g. Becker 2000: 101).

Compared to video cameras, photo cameras are hardly rare in Siberian villages, although a single folklore collector may find it difficult to take a photograph which he or she would be satisfied with. Swedish ethnologist Karin Becker comments on her observation of the multi-ethnic community of an agricultural cooperative outside 
Stockholm that the way how people react to cameras is largely based on cultural traditions. According to her, the Scandinavians were comfortable with being photographed during work, whereas men from the Middle East were extremely opposed to it (Becker 20000: 105). My Siberian Estonian informants' idea of a nice picture - festive clothes, fixed hairdos, posing - would not be to the taste of any folklore scholar, but conveys us important information on the values of the community under study. Can a scholar ignore the rules of the lore community and still take photos that would not be acceptable among the members of this lore group? The use of recording

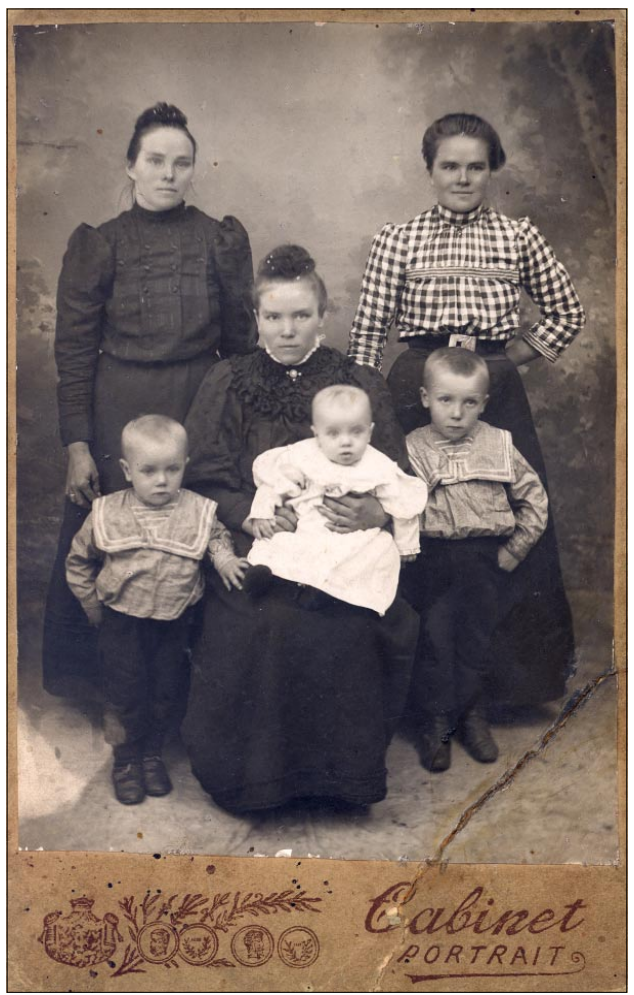

Photo 4. Three sisters and their children, photographed in Yuryev village in the 1920s. Photo provided by Tamara Soots. 
technology in folkloristic fieldwork has greatly contributed to the work, but we cannot disregard the fact that technology still does interfere with human interaction and without technical devices a scholar's relationship with the interviewee would be somewhat different.

\section{d. Collector's gender, age, personal traits}

For a long time collector's personal characteristics were overlooked in the analysis of fieldwork results. The 1970s, however, witnessed a critical shift in folklore studies from text analysis to the individual: a folklorist's role changed from collector to participant-observer (see e.g. Stoeltje, Fox, Olbrys 1999: 167). These changes reflected even in some titles of published studies, e.g. Personal Power and Social Restraint in the Definition of Folklore by Roger Abrahams (1971), Women and Folklore by Claire Farrer (1975), and others, which discussed the identity and relationship between the researcher and the research subject. Discussions on identity intensified in the 1980 s, as several degree theses on field techniques were written at universities in Texas and Indiana. There women often discovered the "objective" misconception and concluded that their identity as a woman affects their study and field relations (Stoeltje, Fox, Olbrys 1999: 172-173). The subjective female influence on fieldwork studies has also been analysed in the recent decade - the most illustrative example being, perhaps, the collection Feminist Dilemmas in Fieldwork, published in 1996 and edited by Diane Wolf. Analogous issues of male researchers in archaic lore communities (see Goldstein 1964: 55-56) have been discussed.

During my fieldwork among the Estonians in Siberia I clearly sensed how my personal characteristics interfered with my work. I intend to point out the most conspicuous ones in the following.

In traditional patriarchal (village) community gender roles are strongly established. It is generally acceptable for a man to leave his family for work, etc., but not for a woman. Women are allowed to work, but their ultimate responsibility is to take care of the family. This triggered a host of personal questions from my informants concerning my marriage and family. The main question for them was how I could leave my family to do field research. Presumably, 
analogous questions have been asked from many women doing research in folkloristics (see e.g. Nájera-Ramírez 1999: 191). The lore community's attitude towards a young single female researcher might not be particularly tolerant either. The most common view is that she must have a personal motif besides the study - she must be looking for a husband. To some extent, a woman conducting fieldwork always has to consider that her role might appear suspicious to the members of the lore community. She might become the target of indecent proposals and must behave to maintain the respect of the community.

At times being a woman may even be advantageous: human sympathy may sometimes make an informant to be more forthcoming with any kind of help, information: to suggest new informants, take the researcher to an old village site or a place connected to lore, etc. Interviewer's personality may also hold the informant back: the informant may be embarrassed, withholding the lore he or she might regard as obscene, or become extremely critical of what he or she knows. An interviewer who cannot remain indifferent might still be able to perform his or her function quite successfully.

There are several other rules that a folklore collector has to consider. For example, if there is at least one man among the fieldwork group, the village community may not accept his doing his own washing, cooking, etc. These chores are traditionally women's chores, and the Siberian village people believe that a man, especially one who travels with several women, should not be taking care of himself.

The interviewer's gender may influence the course of the interview as to which questions can be asked and how to formulate them. My being a woman made it much easier for me to inquire about the traditionally female topics. A female conversation partner may confide to other woman things that she would never tell a male interviewer and which in such a situation would never come up (at least not without the interviewer's initiative). She may introduce an important topic for her, and, in her opinion, also for the female interviewer - namely, instructions how to deal with a drunken aggressive husband. The problem is very topical in the Siberian villages these days: 
- And if, doesn't your husband drink?

- No.

- And doesn't lay hands on you?

- No, he doesn't.

- Look, if a dead person is, you see, weak, the legs are tied together,

- Yes.

- Tied up. And the hands are tied on some. Then this ribbon has to be taken off,

- Yes?

- What is used for tying: hands and legs. And whose husband lays hands on her, and drinks and lays hands on her, then with this ribbon, when he is drunk, you must tie his hands - and he won't.

- You see!

- Yes, he won't lay hands on her. You have to take this ribbon.

CD-0010 (55) < Kovalyovo village < woman, born in 1905 (1997).

A male interviewer may have been told this information, if he had been able to establish a trusting relationship and on his own initiative, but the purpose would have been altogether different.

Unfortunately there was no opportunity to find out whether a young unmarried female interviewer would have received the same instructions by the informant. The collected material also depends on interviewer's age and personal characteristics. An informant of a more advanced age sometimes cannot take a younger interviewer seriously enough to enter into dialogue, or most of the information given to the interviewer is of didactic nature. Interviewer's and interviewee's different understanding of roles may considerably affect the style and understanding of the performed text (Briggs 1986a: 57-58). An informant generally responds differently to different interviewers, as it happens in real life. Therefore there is a demand for as different interviewers as possible (men, women, young, old) to keep the relationship more versatile.

If a folklore collector brings along a companion of the opposite sex to the interview, it will have a direct impact on collection work (see Ives 1995: 70-71). An informant may even take up some topic in the presence of a male interviewer, but may be embarrassed to comment on some aspects of it. I was once visiting an elderly woman 
with my husband. I had had a long conversation with the informant a year prior to this visit, and the woman was very pleased to see me. She started, although hesitantly, to tell me a story about a man who was bewitched. Having reached to the part of the story where she was supposed to explain how the man was bewitched, she began to feel uneasy:

- [---] Let me tell you some other time, maybe. This story stops here. I will not tell you more, what had to be done, when and how.

- So she told you what had to be done?

- Yes. She told me. But I feel uncomfortable telling about it. Let it be, another time. /Chuckling/ Next year, when you'll come, I will tell you. [---]

- [When my husband left the room, the woman commented with relief] Went out.

- Yes, went out.

- [Confidingly] Then she told me. Don't put it on the tape! Should not, what I will tell you now. Should not, this cannot go there. [---] [Then followed an instruction how to bewitch a man to be yours. Having told the story the woman considered it important to seriously warn me against doing that] You should not do that. If there are children, there will be trouble, with children [---]

CD-0460 (1) < Ryzhkovo village < woman, born in 1913 (2000).

Therefore, the woman told us most of the story, but her natural shyness kept her from sharing the most secret part of what she knew with a male interviewer - this was not intended for men. She would never have told the whole story, a part of traditional religious lore, to a male interviewer. Her warning me indicates that she takes the story seriously, that she believes in witchcraft.

This poses a question: has not the fact that folklore collectors during the past recent decades have been mostly women started to affect fieldwork results? 


\section{FACTORS DEPENDENT ON MEMBERS OF THE LORE GROUP}

\section{a. Self-control of the lore transmitter}

Transmitter of folklore often decides what can and cannot be told to the interviewer. An oral account therefore undergoes performer's scrutiny (see e.g. Tedlock 1983: 292). The criteria for evaluating the suitability of lore vary in different regions, and depend on collective and individual values. The criteria judging the obscenity of lore are generally stricter than those among native Estonians. The norms may be bended under the influence of alcohol, but later the informant may regret the spontaneously told stories: Oh, now this will go to Estonia. This won't do. Obscene folklore may be even performed to an interviewer who is regarded as trustworthy, though mostly after the tape-recorder has been switched off.

The singing of some songs is problematic for a singer from the very start: on the one hand he or she may wish to sing, but on the other hand the singer feels that the song is too impolite to be performed to a stranger, for example:

- And then there was, wait... How it... What song was this one like... He sometimes played it, and in the beginning this is how they sung:

- How did the song go?

- [Singing] Kilumari, Kilumari tuli randast,

Kilu Mari, [name 'sprat spawn'] came from the shore, tuli randast, tuli randast.

Came from the shore, came from the shore.

Kusi aga tilkus pastlakandast,

Piss was drippling from sandal heels

pastlakandast, tral-lal-laa. Sandal heels, tral-lal-lah.

:,: Kilumari, kilumari, tule sa,

:,: Kilu Mari, Kilu Mari, come,

aita siga kaubelda. :,:

And help to sell the swine :,: [---]

This cannot be sung like that. [---]

RKM, Mgn II 4366 (8) < Upper Suetuk village < woman, 65 yrs (1991) 
During her performance the singer is losing her self-confidence, she is blushing and comments that this song should not be sung, and will not finish it.

The lore that remains untold may sometimes not even be obscene. The lore transmitter's control of the material may manifest as selfjustification, like in the following revenant account:

- My parents tell so, told so, but it hasn't happened to us.

- What did they tell?

- That it returns, the dead returns home and...

- But why does it return home?

- Well, something's not been done right, then, has not been buried properly, or something. But I, we, never had anybody. I buried my son, and my mom here, and dad died, and, well, then my brother died, I have two brothers here, and two in the battlefield. And, but we have nobody, nobody coming back home. And we haven't heard at all about, oh, somebody has come back, but it has happened, people have spoken, that they come back. And that, I don't know, we have not.

- But what did your parents then tell, what do you have to do to keep it from...?

- What do you have to do? You go to the funeral and... and leave money there, poke silver money near the cross. And then it stops coming. And then people said, the really old ones said that it had visited home and banged and then left in peace, and the grave was all dug up and it was twisted in the grave.

- Huh.

- These very old people told, but I don't know. We haven't, we, it hasn't happened to us, everything is fine with us.

RKM, Mgn II 4366 (8) < Upper Suetuk village < woman, 65 yrs (1991).

The narrator's repeated emphasis on "it hasn't happened to us" and her confirmation that "everything is fine with us" in the end indicates her need to justify herself and protect her family. The informant goes a long way to prove the interviewer that no established norms are violated in her family. 


\section{b. The (social) control of village community}

There is an established system of values and social control governing it in all (village) communities. What is known for insiders is not meant to be shared with outsiders. In a Siberian village such social control may be even more noticeable than in Estonian villages today. If a group member is willing to inform of something that other members would not approve, they will try to stop him or her. Group pressure is often the cause of leaving out specific folklore accounts or presenting the abridged versions, leaving out a part that is for some reason considered unsuitable:

Interviewer: Did you sometimes sing songs in mixed Estonian and Russian language? In the way that some words were in Estonian and some in Russian?

Female informant 1: Wait-wait! I knew one with mixed Estonian and Russian.

Female informant 2: Miku knew one. [The man laughs.] What was there again...?

Male informant: This is sung when... one is already completely...

Female informant 1: completely in one's cups.

Female informant 2: The verse was in the Estonian and the refrain in Russian.

Female informant 1: Well, this must be the one that I was talking about.

Female informant 2: I don't know.

Interviewer: Will you sing it then? [---]

Male informant: This is too rude. [---]

RKM, Mgn II 4371 (10) < Upper Suetuk village < women, born in 1930 and in 1932 and man, age 67 (1992).

They all probably knew the song, but the group considered its recording improper. This certainly raises the issue which songs can be considered obscene. On a gathering in the village of Kovalyovo, for example, our hostess sung a song that caused embarrassment and condemnation among men. The performer, who had a high social position in the village community, daringly justified it: The words cannot be taken out of the song! A performer of folklore may not always understand the message of the performed material differently than the other members of the group. In the following exam- 
ple the informant tells a story of her family, which other informants consider offensive:

- Well this old Kustas of Turku was from Finland. Turku, was it a county or something, or a town, or I don't know what it was. This name, Kustas of Turku stuck to him for the rest of his life. And even we are to this day. But the stepmother was from Estonia, a Kadri. She was sent here, huh, was here because of infanticide.

- [Husband forbiddingly] Oh that...

- [A woman who was also in the company] Don't talk about that.

- Well, how, because what was left there in the flax pond. [---] RKM, Mgn II 4371 (14) < Upper Suetuk village < woman, age 65 (1992).

The long period of time between the event and the narrating situation appears to encourage the informant to talk about this. The forbidding of other conversation participants restrains the informant's talk, causes hesitating - the careful choosing of words after that is very characteristic of that, but there will be no more talk about the story.

Sometimes, in-group control is based on other reasons - members of the group are concerned with passing on the lore, trying to recall a specific story together, carefully observing the recording of the account, e.g. the narrator's distance from the microphone, and finishing the already started story.

Interviewer: Wait, how did it happen then?

Male informant: Who was it who died?

Female informant 1: Wife, I think. And he..

Female informant 2: No, this other Mihkel of Jurtsi? Luukas.

Female informant 1: Well, Miku too!

Female informant 2: Well he did visit Miku, Miku...

Male informant: Yes, yes, yes, yes, yes, right, right.

Female informant 2: ...that Luukas this way.

Male informant: Yes, Old Luukas, yes...

Female informant 1: Well, now I remember...

Male informant: ...had died and Mikk of Jursi lived there, the room where Luuka lived. And then it was heard, how [he] treaded above the chamber ceiling. 
Female informant 1: Tossed peas all around and, like peas. Interviewer: Really! And how did he get rid of it then? Male informant: Well, I don't remember now, what did they... Female informant 1: In the old days.

Female informant 2: You speak first. Wait a minute, Vladimir was saying. They say that he was turned around in the grave, this Luukas. Vladimir, speak it, then, or my voice won't reach there.

V. L. [Laughing]: Well, did he, did he then too, I don't know? N.E.: Here you go. Speak then, if you have already starting telling. [---]

FA DAT 48 (85) < Omski Oblast, Yuryevka village < Novikovka village < man, born in 1927; women, born in 1920 and 1928 (1996).

While recording songs the collector may encounter similar problems than the one described in the above story, although during singing the song's flowing performance is of importance to the lore group. Thus, singing to a folklore collector may be perceived as a performance by members of the lore group (see also Ives 1995: 60). Folklore ensembles were very popular in many Estonian villages in Siberia during the period following the World War II until the 1990s: Estonian songs were specially learned for performing (at village parties, folklore festivals, etc.). Singing to a folklore collector is analogous to special performances: the song may be abridged, verse reiterations or even full verses omitted, in case the performer has forgotten them, considers them unnecessary or they seem inappropriate. Performing a shorter song is also easier, as singers perform only these verses that they remember well. If a round-game song is performed without movement, refrains after each verse are often omitted. It is also important to remember that everything performed to the folklore collector is no longer in active usage. If a folklore collector wishes to record the whole song, he or she needs to convince performers that confusion and interruptions, etc. are allowed, that the recorded material can be edited afterwards, etc.

Siberian village community is relatively conservative and close: the song repertoire of outsiders from other Estonian villages in Siberia is rarely adopted. For example - a woman from Vambola village who had moved to the Kaseküla village some 30-40 years ago had acquired the traditional song repertoire of the Kaseküla village, 


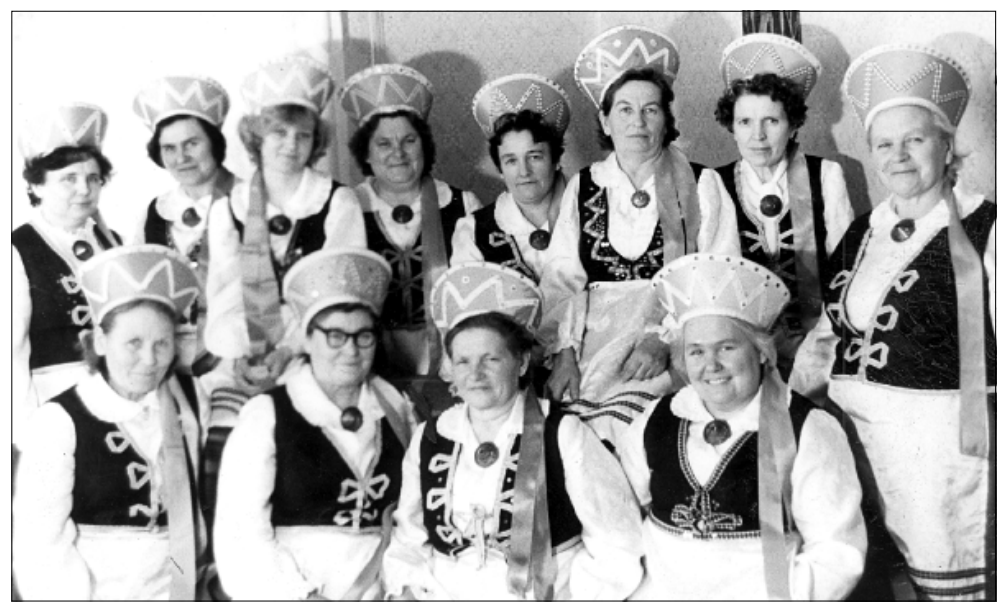

Photo 5. Estonian vocal ensemble in Tsvetnopole village. EFA photo archives, photo no. 16080.

but did not enrich the community repertoire herself, as other song variants were simply not recognised there: This is not how we used to sing it! Later, the newcomer could perform the songs she knew, but had to perform them alone.

The restricting regulations of the village community must be considered everywhere. There is an unwritten rule in several Siberian villages that the death of a close relative permanently ends a singer's singing career. The single singers who dare to violate the rule are strongly condemned by the community. The people of Ryzhkovo village, for example, openly criticised the best singer in the village: Her daughter's dead, but she keeps on carolling! Women of the village of Estonka, who used to be well-known in the region, had not sung for three years following the departure of one singer's brotherin-law and agreed to perform only to collectors from Estonia.

These Estonian singers whom we encountered in the Siberian villages are very likely the last of their kind. In some places (the village of Kaseküla, for example) attempts have been made to teach the young some Estonian songs in order to preserve the ancestral tradition, whereas the younger generation may recognise the Esto- 
nian song lore of the older generation, but will not pass on the tradition.

\section{c. Lore group leader}

As the time that collectors can spend in a village is limited, a scholar may not be able to adequately assess the real relationships between members of the lore group. Leaders as well as outcasts, however, stand out among others. A collector may not even meet the outcast, as he or she is often not referred to. In the Estonian villages in Siberia, a folklore collector tries to interview as many Estonianspeaking people as possible and usually encounters an informant whose visiting is not approved by other members of lore community: his or her knowledge is considered inadequate, even unimportant, and the outcast's home may be considered too untidy for receiving a visitor, etc. A pariah in a village community may sometimes prove a valuable finding for a folklore collector, an informant of a wide range of extensive knowledge. After visiting such an informant a folklore collector usually stays in good terms with other villagers, although an outcast cannot be asked to sing or converse with others.

In a Siberian village community, leaders usually fulfil a certain function - they perform rituals, or are healers, etc. Profession is very valuable in a village community and usually there is no competition, as there is always a lack of skilled people. The leader role became particularly evident for the folklore collector among the group of singers. When asking a Siberian Estonian informant to sing a song, he or she desperately tried to convince someone to sing along, explaining that a song sung alone does not sound as it should, or something like that. For the Estonians in Siberia the right way to sing is group singing, often polyphonic. Polyphonic are also the songs that are usually performed monophonically in Estonia. The Estonian tradition of rhymed folk song is mostly monophonic. A collector usually fails to form a specific song group, as he or she may rely on the singing skills of lore group members, but the intricate relationships of villagers will often remain impenetrable for him or her. 
In Siberian villages collective singing follows its established rules: the song is generally known, but the key singer has a say in singing. I use the term key singer, as it seems to be the most appropriate in this occasion - a key singer leads or guides the singing. Key singer's position is somewhat analogous to that of a storyteller, musician, or healer - he or she has the authority and respect of the group. Parallels could also be drawn with the role of lead singer in runo song tradition (Kõiva 1964: 28), although the role of a lead singer probably involved more responsibility than that of a key singer. The emergence of rhymed folk song introduced brilliant performers of this new song style, creative personalities, who were not merely limited to reproducing the heard songs. Lauri Harvilahti (1992: 24) has distinguished between three types of singers of older song cultures: i) passive singers, who repeat songs as fixed entities, ii) innovative singers, whose composition is more flexible and personal, and iii) singers who improvise freely. In terms of rhymed song tradition the categorisation may be more or less the same, although here scholars have to consider printed sources, song teachers and other influences. In Siberia, printed sources are less available than in Estonia, but the importance and therefore also influence is also greater.

A key singer is able to improvise on the traditional variant of a song, modifying it according to the situation. A typical modification, for instance, is replacing toponyms and personal names with local place names and names of acquaintances. The changes may even be quite considerable - in the village of Kovalyovo the reason of an elderly woman to alter a song's lyrics was the small number of men in the village in the period following World War 2:

Me olime ilma miesteta, siis me olime muidugi vaesemad kui jälle kellel mehed olid. No ja siis me laulsime niimoodi. [---]

Kellel mies on, sie sõidab täkuga, ja kellel meest ei ole, see käib käruga.

Las tiab, las tiab, las tiab kõik maailm, ja kellel miest on ja kellel ei.

Kellel mies on, sie ostab siidisukki, ja kellel miest ei ole, sie laseb paljal päkki.

Las tiab, las tiab, las tiab kõik maailm, et kellel mies on ja kellel ei. 
We had no men, then we were, of course, poorer than those who had men. And then we sung like that. [---]

Who has a husband, rides with a stallion, and who doesn't have a husband, pushes a barrow.

Let, let, let the whole world to know, Who has a husband and who has not.

Who has a husband, buys silk stockings, And who hasn't, walks barefoot.

Let, let, let the whole world to know,

Who has a husband and who has not.

CD-0012 (20) < Kovalyovo village < women, born in 1915 and in 1906 (1997).

A key singer may replace a forgotten part of the lyrics with what he or she considers suitable in the context: I couldn't remember how it went, so we put something else instead; sometimes the forgotten tune may be replaced with another one: Didn't know the tune and used their own.

A key singer may sing some songs with different tunes (e.g. Estonian songs Siidilipp ja hõbepurjed 'Silk Flag and Silver Sails' and Oh ütle, kena neiuke 'Oh, Tell Me, Sweet Girl') - depending on which he or she considers suitable in the situation.

In Siberia a person could become a key singer owing to his or her prominent work and/or profession. Linda Tsirk from the village of Tsvetnopole and Juhanna Müller from Yuryevka village worked as cultural managers and also led the local folklore ensemble, Herman Reile from Kaseküla village was a singing teacher at local school and supervised singing groups, Rosalie Taits from the village of Zolotaya Niva took over supervising the Estonian folklore ensemble, when its former leader Ida Hõim retired due to old age.

The song repertoire of villages depends largely on the key singer who determines the use of folk songs or newer popular songs, changes in the repertoire, etc. Some key singers (e.g. Linda Tsirk from Tsvetnopole village) are more innovative, favouring author songs, and their preferences are also reflected in the village song repertoire. 
In Siberian villages, singing is generally initiated by the key singer. If the song is well known, others join the key singer after the first syllables. If the song is less known, a lead singer will usually sing the first lines or even the full verse, before others will join. Very few rhymed songs have been sung analogously to singing folk songs in runo verse: the key singer sings the lines and the choir repeats them. Singing is rarely started all at once, unless the song has been learned for performance, and then the key singer signals with a hand gesture, a nod, etc. Key singer's version is generally strictly followed, although there may be minor variations in the lyrics used by the key singer and the choir. The key singer then determines the performance (setting the pace, tune, iterations, and, if necessary, the movement of the song).

Groups with no major conflicts may even have several key singers and the right to initiate the song is passed from one to another without major problems. In several Siberian village communities there is constant rivalry between singers. Analogous rivalry in Estonia has been noted among the Setu singers. In Siberia the right to take up a song is usually given to the singer on whose premises (at home, at relatives or friends) the singing takes place. The right to start specific songs may belong to one group member only, and in his or her absence the song is not sung. Such is a song about a man's deportation to Siberia, sung in the village of Kovalyovo, which was attributed to one member of the lore group: Aleksander, this is your song, you start! Of course, Aleksander was not the song's author, but the song belonged to his repertoire, and the song was believed to have been written by his distant ancestor. This is analogous to narrating specific folk tales, as some are also attributed to specific persons (see e.g. Hiiemäe 1978: 49).

Key singer's departure (death, moving) or withdrawal from singing (mourning in the family, serious illness, religious awakening) nowadays often means the disappearance or Russianisation of the village's song tradition. Often there is noone else who knows the Estonian song repertoire and could become a new key singer. 


\section{d. Informant rivalry}

From a collector's point of view, informant rivalry may sometimes even be favourable, as the informants try to outrival each other in providing information and explaining things. Here, however, I would like to address another, hindering aspect of the issue by means of a specific example.

In the village of Ryzhkovo I met two sisters, who were fairly good informants, but widely different in personality and knowledge. One of the sisters was quiet and reserved, the other one energetic and lively. The former knew healing spells and was quite familiar with religious lore. I met her first and she trusted me from the first moment and was very helpful. When I began to question her about songs, she asked her sister to join us, explaining that she herself had forgotten most songs of her youth. Apparently I paid more attention to her sister, so that I could notice almost a feeling of jealously between them - either sought attention and they bickered constantly with each other:

[---] You had no husband, came and went as you liked, sung songs, but I was with my husband, sat at home, how could I do that... - Your husband sung too.

- And what if he did. That much he did, how often did you and my husband sing together anyway.

- While we were drinking backstage, then we sung.

- And when was that, years ago. What's there to talk about. But you were alone, too, then there and there and yes you sung and were around.

- I wasn't old, I was 18 when I married, I was no spinster.

- All right you weren't, but you still had time to go out. I couldn't, I don't know, anywhere...

- But it was better to stay at home and study.

- We sat outside the gate at home. [---] And they ran, and all. But I was young, married, and before I couldn't go anywhere, mother wouldn't have let me, and I listened. And late at night, so should be back at home, at dusk, should be at home. I listened, but she, she did not listen. [---]

CD-0306 (17) < Ryzhkovo village < women, born in 1913 and 1916 (1999). 
The sister who had grown tired of singing, and especially of her sister getting all the attention, could no longer hide it and tried to cut the stories shorter: making the other sister skip reiterations, even whole verses, saying: This takes too long. You sing it twice, then it takes so very long. A song lasting for a year. EFA I 38, 123 (10) < Ryzhkovo village < woman, born in 1913 (1999). Trying to avoid a major conflict I could not let them continue.

\section{e. The influence of family members on the repertoire of informant.}

It is quite common in Siberia that not all family members can speak Estonian, especially the younger ones. In mixed marriages communication usually takes place in Russian. A folklore collector often finds himself or herself in a difficult situation in such families. As a guest, he or she is expected to speak a language that everyone understands, but as a folklore collector s/he would prefer interviewing in Estonian. In a friendly family where people look after each other the collector is usually granted some time alone with the elderly informant. Younger family members may sometimes even be flattered by the attention that their elderly family member has attracted. Quite often a daughter leaves for her own chores so that her mother could speak alone with the folklore collector. If children understand the Estonian language, they may try to help the informant to remember something that they have heard before, asking leading questions in Russian. And sometimes the younger generation has nothing to add to their parents' story, but stay there for moral support, instilling confidence in the informant.

Interviewing is much more problematic in the presence of a husband of low self-esteem, who disregards his wife's wishes. My collection work at a 70-year-old woman in the village of Zolotoye Niva was interrupted because of her Ukrainian-born husband. I visited the family when both of them were at home. I introduced myself and made small-talk in Russian. Then I moved on to interviewing the wife in Estonian. We talked about how her parents had arrived in Siberia, the time of Soviet collective farms, repressions. Her husband started fidgeting and warned his wife to carefully consider what to tell the foreigner. First I thought that he understood what 


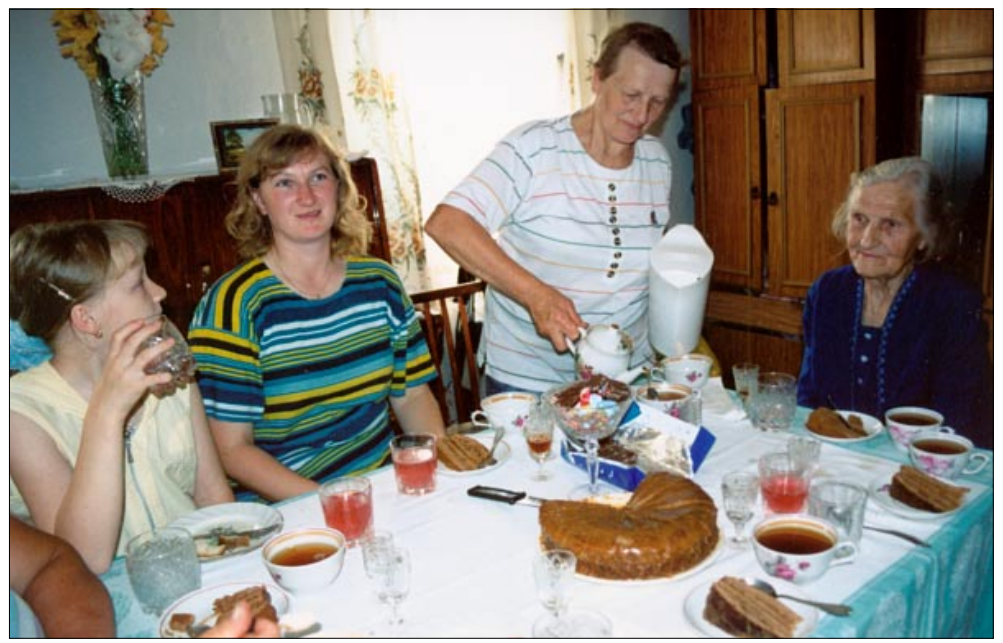

Photo 5. Four generations of women at the table in the Kaseküla village. Photo

we were talking about and I decided to choose a more neutral subject - I asked about local wedding customs, birthday celebrations, etc. After a while the husband barked at his wife again: Dumaesh'o chem govorish? 'Are you thinking what you are talking about?' The woman furtively looked towards the tape-recorder and asked me blushing of embarrassment: So did you get everything you wanted? This should be all, don't you think?

I felt uncomfortable in this situation, too and to prevent the situation from getting worse, I left. Later I heard that her husband doesn't understand a word of Estonian and demands speaking in Russian in his presence. I would have been able to interview the woman only outside her home, without her husband knowing.

\section{CONCLUSION}

Collectors of oral narrative history cannot disregard their cultural, social and educational background, traditions and instruction, and use the methods that are used in their native culture. They always have to remember that their knowledge and skills (being compe- 
tent in the communication system of a given lore group, the use of technical devices, working style, etc.) and age, gender and characteristics directly influence the result of collection work. The collector's influence on members of a given lore group is stronger than we may think. During an interview a collector makes the informants think of something that they normally do not think about, or makes them think about it differently than they are used to. In interviewer's presence people begin reassessing the values of the lore community. Speaking of Estonians in Siberia, there is another aspect that needs to be considered - Estonians in Siberia feel certain inferiority while communicating with a native Estonian, and an interviewer from Estonia can boost their confidence by displaying genuine interest in their lore. Owing to the relative isolation of Estonian settlements in Siberia, a folklore collector also serves certain socio-political purposes.

At the same time we cannot disregard the influences determined by the lore community (the individual and collective control over folk tradition, the role of the lore group leader, informant rivalry, and the influence of family members on the repertoire of informant).

The result of oral collection work is always subjective, depending on the interaction and cooperation of either parties. A folklore collector will probably never be able to describe the reality of the examined community as it is, but modern technology enables the collector to bring back a part of an informant's reality. Earlier experience in fieldwork and longer working periods in specific lore group help a folklorist to understand the values of the studied community and broaden his or her horizons in the lore worth recording.

\section{References}

Abrahams, Roger D. 1971. Personal Power and Social Restraint in the Definition of Folklore. Journal of American Folklore 84, pp. 16-30.

Aro, Laura 1996. Minä kylässä: Identiteettikertomus haastattelututkimuksen folklorena [Village and Me]. Suomalaisten Kirjallisuuden Seuran Toimituksia 650. Helsinki: Suomalaisen Kirjallisuuden Seura.

Barkalaja, Anzori 2000. Uitmõtteid massimeedia mõjust hantide mõttemaailmale ja mõistepruugile võõrasse keelde tõlkimisel [Reflections on the Impact of Mass Media on the Khanty Worldview and Use of Concepts 
in Translating into Foreign Language]. Kõiva Mare (ed.). Meedia. Folkloor. Mütoloogia. Tänapäeva folkloorist 3. Tartu: Eesti Kirjandusmuuseum, pp. 180-192.

Becker, Karin 2000. Picturing a Field: Relationships Between Visual Culture and Photographic Practice in a Fieldwork Setting. Anttonen, Pertti J. (ed.). Folklore, Heritage Politics and Ethnic Diversity: A Festschrift for Barbro Klein. Mångkulturellt Centrum 2000: 1 Botkyrka (Sweden): Multicultural Centre, pp. 100-121.

Bennett, Gillian 1999. Alas, Poor Ghost!: Traditions of Belief in Story and Discourse. Logan (Utah): Utah State University Press.

Brednich, Rolf Wilhelm 1988. Quellen und Methoden. Brednich, Rolf Wilhelm (ed.). Grundriss der Volkskunde: Einführung in die Forschungsfelder der Europäischen Ethnologie. Ethnologische Paperbacks. Berlin: Reimer, pp. 73-93.

Briggs, Charles L. 1986. Introduction. Briggs, Charles L. Learning how to ask: A sociolinguistic appraisal of the role of the interview in social science research. Studies in the social and cultural foundations of language 1. Cambridge [et al.]: Cambridge University Press, pp. 1-30.

Briggs, Charles L. 1986a. Interview techniques vis-à-vis native metacommunicative repertoires; or, on the analysis of communicative blunders. Briggs, Charles L. Learning how to ask. A sociolinguistic appraisal of the role of the interview in social science research. Cambridge [et al.]: Cambridge University Press, pp. 39-60.

Farrer, Claire (ed.) 1975. Women and Folklore. Austin: University of Texas Press.

Goldstein, Kenneth S. 1964. A Guide for Field Workers in Folklore. Hatboro (Pennsylvania): Folklore Associates [u.a.].

Harvilahti, Lauri 1992. Kertovan runon keinot: Inkeriläisen runoepiikan tuottamisesta. Suomalaisen Kirjallisuuden Seuran Toimituksia 522. Helsinki: Suomalaisen Kirjallisuuden Seura.

Hiiemäe, Mall 1978. Kodavere pajatused: Kujunemine ja koht rahvajututraditsioonis [Stories from Kodavere]. Tallinn: Eesti Raamat.

Honko, Lauri 1998. Folklooriprotsess [Folklore process]. Mäetagused: Hüperajakiri 6. Tartu, pp. 56-84 (cf. http://www.folklore.ee/tagused/nr6/ honko.htm - July 2, 2004).

Ives, Edward D. (ed.) 1995. The Tape-Recorded Interview: A Manual for Field Workers in Folklore and Oral History. 2nd Edition. Knoxville: University of Tennessee Press.

Jackson, Bruce 1987. Fieldwork. University of Illinois Press. Urbana: University of Illinois Press.

Kõiva, Ottilie-Olga 1964. Kihnu rahvalaulikutest. Tartu Riikliku Ülikooli Toimetised 159. Tartu: Tartu Riiklik Ülikool.

Korb, Anu 2000. Ajalugu ja pärimus: Siberi eestlaste jutud oma esivanematest [History and Folklore: Tales about Ancestors among the 
Estonians in Siberia]. Mäetagused: Hüperajakiri 15, pp. 48-64 (cf. http:// www.folklore.ee/tagused/nr15/korb.htm - July 2, 2004).

Lipponen, Ulla 1999. Haigla-rollimäng - tähelepanekuid tüdrukute ja poiste ühismängu kujunemise kohta [Role Play "Hospital". Observations on the Formation of the Game for Boys and Girls]. Kalmre, Eda (ed.). Kuuldust-nähtust. Tänapäeva folkloorist 4. Tartu: Eesti Kirjandusmuuseum, pp. 146-166.

Nájera-Ramírez, Olga 1999. Of Fieldwork, Folklore, and Festival: Personal Encounters. Journal of American Folklore 444: 112, pp. 183-199.

Paredes, Americo 1993. On Ethnographic Work among Minority Groups: A Folklorist's Perspective. Paredes, Americo. Folklore and Culture on the Texas-Mexican Border. CMAS Books. Austin (Texas): University of Texas \& CMAS Books, Center for Mexican American Studies, pp. 73-110.

Pekkala, Armi \& Vasenkari, Maria 2000. Producing Thick Data: An Ingrian Finnish Case. Honko, Lauri (ed.). Thick Corpus, Organic Variation and Textuality in Oral Tradition. Studia Fennica: Folkloristica 7. Helsinki: Finnish Literature Society, pp. 557-593.

Pärtlas, Zhanna 1995. Mitmehäälsuse rollist erinevate rahvuslike folklooritraditsioonide vastastikusel mõjutamisel [On the Role of Polyphony in the Reciprocal Influence of Various Folklore Traditions]. Oras, Janika (ed.). Eksitaja: [Rahvaluule- ja etnograafia-alaste artiklite kogumik]. Pro Folkloristica 3. Tartu: [Eesti Kirjandusmuuseum], pp. 56-58.

Rüütel, Ingrid 2000. Tõde ja eetika visuaalses antropoloogias [Truth and Ethics in Visual Anthropology]. Kõiva Mare (ed.). Meedia. Folkloor. Mütoloogia. Tänapäeva folkloorist 3. Tartu: Eesti Kirjandusmuuseum, pp. 170-179. 